\title{
Detection of Epstein-Barr virus in gastric carcinoma cells and surrounding lymphocytes
}

\author{
Kenji Oda ${ }^{1}$, Keiji Koda ${ }^{1}$, Nobuhiro Takiguchi ${ }^{2}$, Masao Nunomura ${ }^{3}$, Kazuhiro Seike ${ }^{1}$, and Masaru Miyazaki ${ }^{1}$ \\ ${ }^{1}$ Department of General Surgery, Graduate School of Medicine, Chiba University, 1-8-1 Inohana, Chuo-ku, Chiba 260-8670, Japan \\ ${ }^{2}$ Department of General Surgery, Chiba Cancer Center, Chiba, Japan \\ ${ }^{3}$ Department of General Surgery, Chiba Municipal Hospital, Chiba, Japan
}

\begin{abstract}
Background. Epstein-Barr virus (EBV), the etiological agent of infectious mononucleosis, has an important role in the oncogenesis of EBV-related malignant diseases. The association of EBV with gastric carcinoma cells has become well known recently, but there are only a few reports concerning its association with surrounding epithelia and infiltrating lymphocytes. In this study, we investigated the association of EBV with gastric carcinoma and surrounding cells.

Methods. One hundred and two cases of gastric carcinoma were studied. The specimens were studied for the presence of the EBV genome by polymerase chain reaction (PCR), and then by in situ hybridization (ISH) technique to determine the localization of EBV.

Results. Of 97 informative cases, EBV was detected in 21 cases $(21.6 \%)$ by the PCR method. ISH studies showed that EBV RNA was expressed in 5 of the 97 cases $(5.2 \%)$ and was localized to the nuclei of carcinoma cells. All these 5 lesions were found in male patients. In these 5 cases, 3 were diffuse type and 2 were intestinal type, and all cases arose in the proximal region of the stomach. EBV RNA was not detected in non-neoplastic epithelia, but it was detected in 24 of the 97 cases $(24.7 \%)$ in small lymphocytes.

Conclusion. EBV was detected in $5.2 \%$ of gastric carcinomas and in $\mathbf{2 4 . 7} \%$ of infiltrating lymphocytes by the ISH method. The high positive rate $(21.6 \%)$ by the PCR method corresponds to the presence of the EBV genome in surrounding lymphocytes.
\end{abstract}

Key words Gastric carcinoma · Epstein-Barr virus · Surrounding lymphocytes

Offprint requests to: $\mathrm{K}$. Oda

Received: January 6, 2003 / Accepted: June 10, 2003

\section{Introduction}

Epstein-Barr virus (EBV), the etiological agent of infectious mononucleosis, may have an indispensable role in the oncogenesis of EBV-related malignant diseases. It is well known that EBV is associated with endemic Burkitt lymphoma [1] and lymphoepithelioma of the nasopharynx [2-4]. In the past 15 years, EBV genomes have been identified in Hodgkin's disease [5-8], some types of T-cell lymphoma [9], lymphoepitheliomas of various tissues [10-12], malignant lymphoma arising in immunosuppressed patients $[13,14]$, and pyothoraxassociated B-cell lymphoma $[15,16]$.

Burke et al. [17] first reported the association of Epstein-Barr virus (EBV) with gastric lymphoepithelial carcinoma, in 1990, using a polymerase chain reaction (PCR) method. In 1991, Shibata et al. [18] demonstrated that EBV genomes were uniformly present in gastric lymphoepithelioma-like carcinoma cells and were not present in the reactive lymphoid infiltrate or normal mucosa. In 1992, Shibata and Weiss [19] indicated that EBV genomes were present not only in the rare lymphoepithelial gastric adenocarcinoma, but also in $16 \%$ of typical gastric adenocarcinomas in North America. In Japan, Tokunaga et al. [20,21] reported that $6.6 \%-6.9 \%$ of gastric carcinomas were EBVrelated. After that, many authors reported the association of EBV with gastric carcinoma, noting a close relationship to lymphoepithelial morphology, a $6 \%-12 \%$ occurrence in ordinary gastric carcinoma, male predominance, and a higher frequency in the upper part of the stomach [22-28]. But there have been only a few reports concerning surrounding epithelia and infiltrating lymphocytes, and the exact route through which EBV could enter the epithelial cells is unknown. In this study, we investigated the association of EBV with gastric carcinoma and surrounding cells, using a PCR method and an in situ hybridization (ISH) method. 


\section{Patients and methods}

\section{Patients and specimens}

One hundred and two cases of gastric carcinoma were studied. All specimens were obtained surgically from Japanese patients at the Department of General Surgery, Graduate School of Medicine, Chiba University. The mean age of the patients was 61.6 years. The maleto-female ratio was 1.8 to 1 . For histological examination, tissues were fixed in $10 \%$ formalin and embedded in paraffin. Histologically, 40 cases were intestinal type, and the other 62 cases were diffuse type, by Lauren's classification [29]. In this series, one case of adenosquamous carcinoma was considered to be diffuse type, and one case resembled lymphoepithelioma of the nasopharynx. Concerning the depth of invasion, 37 cases were mucosal or submucosal cancer ("early cancer"), and in the other 65 cases, carcinoma cells involved the proper muscle or extended beyond it ("advanced cancer").

\section{Polymerase chain reaction (PCR)}

The specimens were first studied for the presence of the EBV genome by PCR with primers specific for a 153base pair region of the EBV BamHI W fragment (primers: EBV1， 5'CACTTTAGAGCTCTGGAGGA3'; EBV2 5'TAAAGATAGCAGCAGCGCAG3'). DNA was extracted from six 10- $\mu$ m-thick sections of formalinfixed paraffin-embedded tissues by the method described previously $[22,30]$. To ascertain the reliability of DNA extraction, a 110 -base pair region of the $\beta$-globin gene was also amplified (primers: $\beta$-globin $1,5^{\prime} \mathrm{ACA}$ CAACTGTGTTCACTAGC3'; $\beta$-globin $2,5^{\prime}$ CAAC TTCATCCACGTTCACC $3^{\prime}$ ). The PCR mixtures contained $1.0 \mu \mathrm{g}$ of DNA, $5 \mu \mathrm{l}$ of $10 \times$ Taq polymerase buffer $(500 \mathrm{mmol} / 1 \mathrm{KCl}, 100 \mathrm{mmol} / \mathrm{l}$ Tris- $\mathrm{HCl}, \mathrm{pH} 8.4$, $15 \mathrm{mmol} / 1 \mathrm{MgCl}_{2}, 0.1 \%$ gelatin, $0.2 \%$ Nonidet P- 40 ; Sigma Chemical, St. Louis, MO, USA), $200 \mu \mathrm{mol} / \mathrm{l}$ of each deoxynucleoside, 100 pmole of EBV or $\beta$-globin primers, and 2.5 units of Taq polymerase (Perkin Elmer Cetus, Norwalk, CT, USA) in a final volume of $50 \mu \mathrm{l}$. After an initial incubation for $3 \mathrm{~min}$ at $94^{\circ} \mathrm{C}$, the samples were subjected to 30 amplification cycles $(1 \mathrm{~min}$ at $94^{\circ} \mathrm{C}, 30 \mathrm{~s}$ at $54^{\circ} \mathrm{C}, 1.5 \mathrm{~min}$ at $72^{\circ} \mathrm{C}$; complete cycle, $8.5 \mathrm{~min}$ ) in a Thermal cycler (PC-700; ASTEC, Fukuoka, Japan). The PCR products were electrophoresed and visualized by ethidium bromide staining. The sensitivity of this method was calculated as a minimum of 800 copies of the EBV genome in the DNA sample [22]. In each experiment, EBV-containing RAJI cell DNA was used as a positive control, and a sample without DNA was used as a negative control. RAJI cells were a gift from the Japanese Cancer Research Resources Bank (Tokyo, Japan).

\section{In situ hybridization (ISH)}

All cases were also studied by ISH to determine the localization of EBV and to compare the sensitivity with that of PCR. ISH was performed, as we have previously mentioned, by using a digoxigenin-labelled 30meroligonucleotide probe (5'AGACACCGTCCTCACC ACCCGGGACTTGTA3') which was complementary to small nuclear EBV-encoded RNA-1 (EBER-1) [22,31]. Briefly, 4- $\mu$ m-thick sections were cut from paraffin-embedded tissues, mounted on 3aminopropyltriethoxysilan (Sigma Chemical, St Louis, MO, USA)-coated slides, baked at $60^{\circ} \mathrm{C}$ for $1 \mathrm{~h}$, and dewaxed. The sections were treated with $0.2 \mathrm{~N} \mathrm{HCl}$ for $20 \mathrm{~min}$ and then with $20 \mu \mathrm{g} / \mathrm{ml}$ proteinase $\mathrm{K}$ (Boehringer Mannheim, Mannheim, Germany) solution. Then the slides were dehydrated and dried.

The prehybridization mixtures consisted of $50 \%$ deionized formamide, $5 \times$ Denhardt's solution, $4 \times$ saline-sodium phosphate-ethylenediaminetetraacetic acid (SSPE) $(1 \times$ SSPE: $0.18 \mathrm{~mol} / 1 \mathrm{NaCl}, 10 \mathrm{mmol} / 1$ $\mathrm{NaH}_{2} \mathrm{PO}_{4}, 1 \mathrm{mmol} / 1$ ethylene-diaminetetraacetic acid; $\mathrm{pH} 7.4), 0.1 \%$ sodium dodecyl sulfate, $100 \mu \mathrm{g} / \mathrm{ml}$ of denatured salmon sperm DNA, $100 \mu \mathrm{g} / \mathrm{ml}$ of transfer RNA, and $10 \%$ dextran sulfate. After prehybridization for $2 \mathrm{~h}$ at $37^{\circ} \mathrm{C}, 20 \mu \mathrm{l}$ of hybridization mixtures containing $1-2 \mathrm{ng} / \mu \mathrm{l}$ of probe was pipetted onto tissue sections, covered with coverslips, and incubated at $37^{\circ} \mathrm{C}$ overnight. Then the slides were washed.

For the detection of the hybridization signal, the slides were treated for $30 \mathrm{~min}$ with $0.5 \%$ blocking reagent solution (Boehringer), then with polyclonal sheep anti-digoxigenin alkaline phosphatase conjugate (1000$5000 \times$ ) for $30 \mathrm{~min}$. After a washing, the visualizing reaction was performed with nitroblue tetrazolium salt (NBT) and 5-bromo-4-chloro-3-indolyl phosphate (BCIP) solution in the dark for 6 to $12 \mathrm{~h}$. The slides were counterstained with methyl green and mounted with aqueous medium. As a positive control, lymphoepithelioma of the nasopharynx was used in each study. The specificity of the ISH method was mentioned previously [22].

\section{Results}

DNA could be extracted in 99 of 102 cases $(97.1 \%)$ and amplification of the $\beta$-globin gene was observed in 97 of 99 cases $(98.0 \%)$. Of these 97 informative cases, EBV was detected in 21 cases $(21.6 \%)$ by the PCR method (Fig. 1; Table 1). ISH studies clearly showed that EBV RNA was expressed in 5 of the 97 cases $(5.2 \%$ ) (Table 1) and was localized to almost all nuclei of carcinoma cells (Fig. 2). These 5 cases were all clearly PCRpositive (Fig. 1). 
Clinically, all the above five lesions were found in male patients and arose in the proximal region of the stomach. Concerning depth of invasion, one case was submucosal cancer ("early cancer"), and in the other four cases, the cancer had invaded the proper muscle or beyond ("advanced cancer"). Histologically, three of the five cases were diffuse type and two were intestinal

\section{$\begin{array}{llllllllllll}1 & 2 & 3 & 4 & 5 & 6 & 7 & 8 & 9 & 10 & \text { N P }\end{array}$}
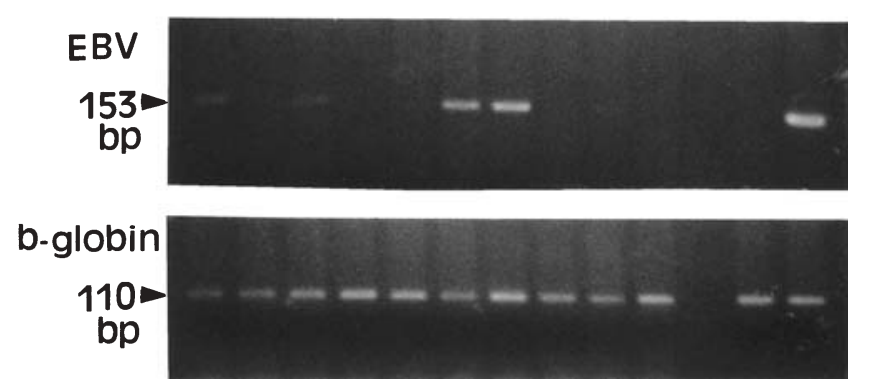

Fig. 1. Example of polymerase chain reaction (PCR) study for detecting Epstein-Barr virus (EBV)-DNA. Lanes 1,3,6, and 7 were EBV-positive (lanes 1 and 3 were weakly positive; lanes 6 and 7 were clearly positive). Amplification of $\beta$-globin DNA was successful in all cases. $N$, EBV-negative control; $P, \mathrm{EBV}$ positive control type, by Lauren's classification. One case was typical lymphoepithelioma-like carcinoma similar to nasopharyngeal carcinoma, and moderate lymphoid infiltration was observed in the other two cases of EBV-positive diffuse-type carcinomas (Table 2).

In this study, EBV RNA was not detected in the nonneoplastic epithelia adjacent to carcinoma cells, but it was detected in 24 of the 97 informative cases (24.7\%), in a few scattered small infiltrating lymphocytes in the lamina propria, by the ISH method (Fig. 3). In the EBV-positive carcinomas, EBV-positive lymphocytes were observed in 4 of the 5 cases $(80.0 \%)$, which was a significantly higher positive rate than that in EBVnegative gastric carcinomas ( 20 of 92 cases; $21.7 \% ; P=$ 0.01 , Fisher's exact test) (Table 3 ). The maximal density of EBV-positive lymphocytes was 1-4 per high-power field $(\times 200)$ in all EBV-positive cases.

Table 1. Results of polymerase chain reaction (PCR) and in situ hybridization (ISH) studies

\begin{tabular}{lcc}
\hline & PCR & ISH \\
\hline EBV-positive & $21 / 97(21.6)$ & $5 / 97(5.2)$ \\
EBV-negative & $76 / 97(78.4)$ & $92 / 97(94.8)$
\end{tabular}

Figures in parentheses are percentages

Table 2. Clinicopathological findings of EBV-positive gastric carcinoma

\begin{tabular}{lcccccc}
\hline Case no. & Age (years) & Sex & Location & Depth of invasion & Histology & Other features \\
\hline 1 & 59 & M & Cardia & Proper muscle & por 1 & Lymphoid infiltration \\
2 & 57 & M & Cardia & Submucosa & tub 2 & \\
3 & 68 & M & Cardia & Subserosa & por 1 & Lymphoepitheloma-like carcinoma \\
4 & 61 & M & Body & Subserosa & por 2 & Lymphoid infiltration \\
5 & 52 & M & Body & Proper muscle & tub 1 & \\
\hline
\end{tabular}

tub 1, well differentiated tubular adenocarcinoma; tub 2, moderately differentiated tubular adenocarcinoma; por 1, poorly differentiated adenocarcinoma, solid type; por 2 , poorly differentiated adenocarcinoma, non-solid type

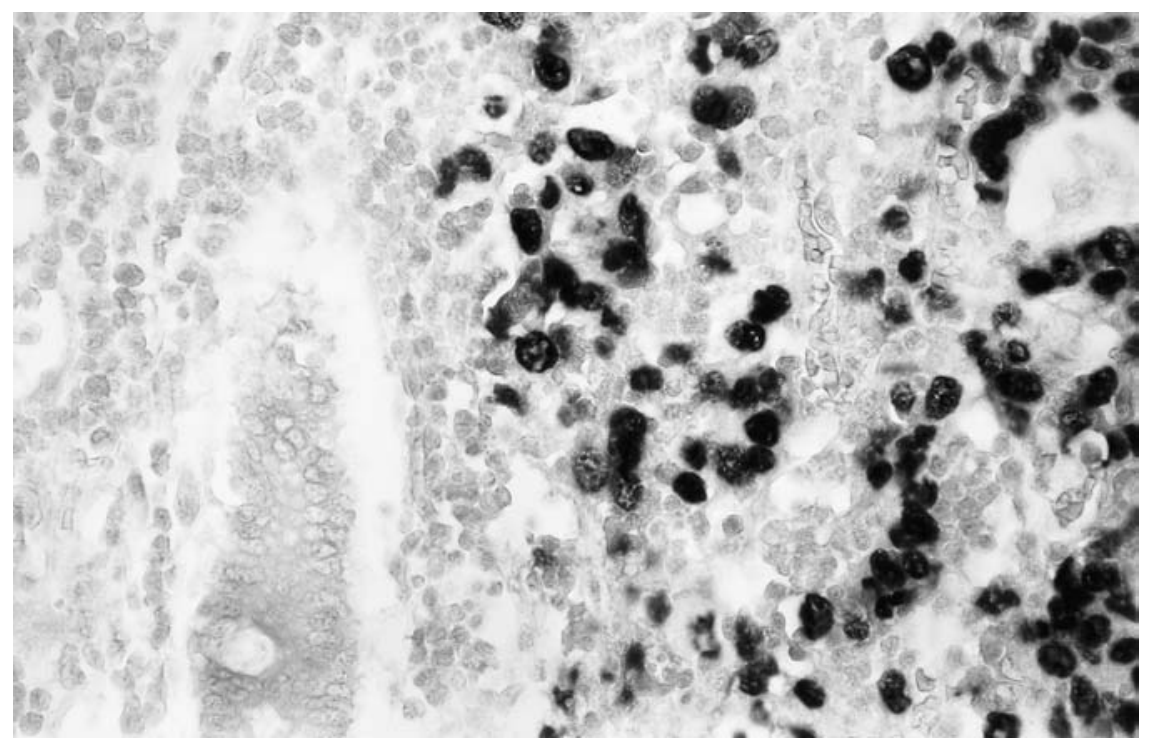

Fig. 2. In-situ hybridization (ISH) study for detecting EBV-RNA. Strong nuclear staining was observed in carcinoma cells. In this case, non-neoplastic epithelia and infiltrating lymphocytes were EBVnegative, $\times 164$ 


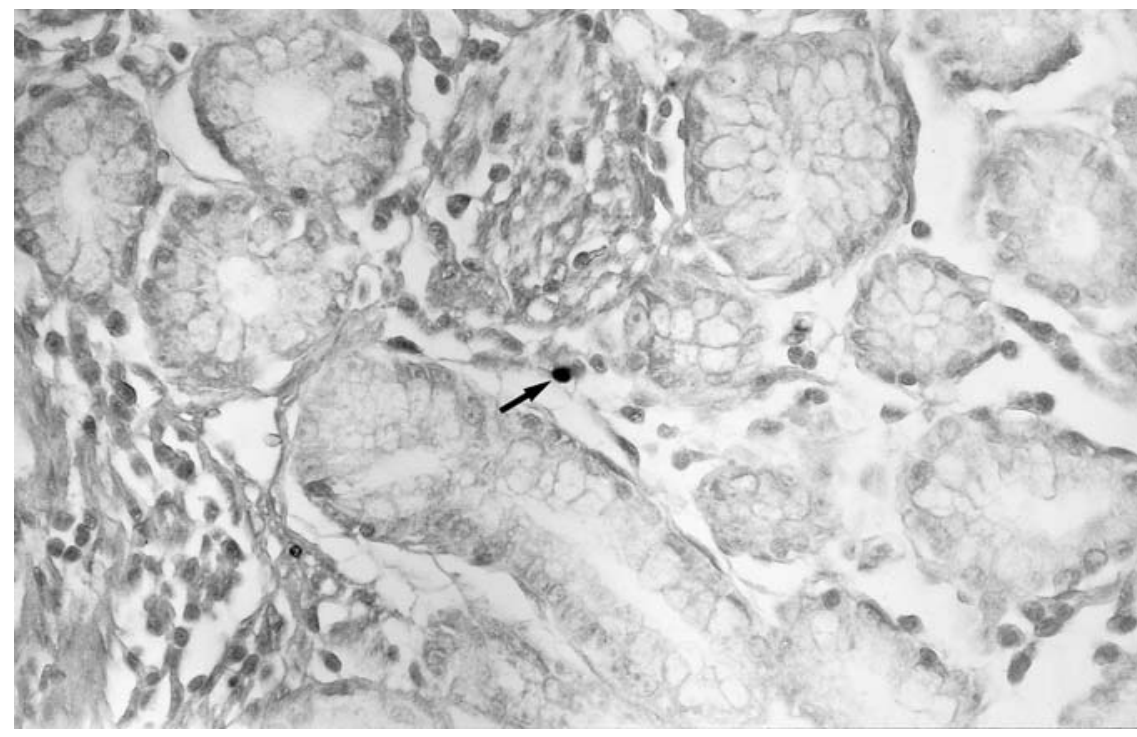

Fig. 3. EBV RNA was detected in small infiltrating lymphocytes (arrow), by the ISH method, but was not detected in nonneoplastic epithelia, $\times 164$

Table 3. Association of EBV-positive gastric carcinoma and the presence of EBVpositive lymphocytes

\begin{tabular}{lccr}
\hline & $\begin{array}{c}\text { Presence of } \\
\text { EBV-positive } \\
\text { lymphocytes }\end{array}$ & $\begin{array}{c}\text { Absence of } \\
\text { EBV-positive } \\
\text { lymphocytes }\end{array}$ & Total \\
\hline EBV-positive gastric carcinomas & $4(80.0)$ & $1(20.0)$ & 5 \\
EBV-negative gastric carcinomas & $20(21.7)$ & $72(78.3)$ & 92 \\
\hline
\end{tabular}

$P=0.01 ;$ EBV-positive gastric carcinomas vs EBV-negative gastric carcinomas

Figures in parentheses are percentages

Table 4. Results of ISH and PCR studies, excluding EBVpositive gastric carcinoma cases

\begin{tabular}{lccc}
\hline & ISH-positive & ISH-negative & Total \\
\hline PCR-positive & 6 & 10 & $16(17.4)$ \\
PCR-negative & 14 & 62 & $76(82.6)$ \\
Total & $20(21.7)$ & $72(78.3)$ & 92 \\
\hline
\end{tabular}

Figures in parentheses are percentages

Concerning EBV detection methods, our results showed no association between the PCR and ISH methods in the 92 cases of EBV-negative gastric carcinomas (Table 4). There were no significant clinical differences between the clinical characteristics of the PCR-positive and/or ISH-positive-lymphocyte cases and bothnegative cases (Table 5).

\section{Discussion}

The association of Epstein-Barr virus (EBV) with gastric lymphoepithelial carcinoma was first reported by Burke et al. [17] in 1990, using a PCR method. In 1991, Shibata et al. [18] demonstrated by PCR and ISH methods that EBV genomes were uniformly present in gas- tric lymphoepithelioma-like carcinoma cells and were not present in the reactive lymphoid infiltrate or normal mucosa. But in one of their seven cases (14.3\%), an EBV sequence was detected in the normal mucosa, and an EBV sequence was detected in one of six normal lymph nodes (16.7\%) by a PCR method [18]. Our previous report indicated that the EBV genome was detected by PCR in one case of normal gastric mucosa, which was negative by the ISH method [22]. In 1992, Shibata and Weiss [19], using PCR and ISH methods, demonstrated that EBV genomes were present not only in the rare lymphoepithelial gastric adenocarcinoma, but also in $16 \%$ of typical gastric adenocarcinomas in North America. In Japan, using an ISH method, Tokunaga et al. $[20,21]$ reported that $6.6 \%-6.9 \%$ of gastric carcinomas were EBV-related. Many authors have reported a $6 \%-12 \%$ association of EBV with ordinary gastric carcinoma [22-28]. In our study, EBV was detected in $5.2 \%$ of gastric carcinomas by an ISH method, supporting the results of these studies.

However, there have been only a few reports concerning the association of EBV with surrounding epithelia and infiltrating lymphocytes. In 1994, Fukayama et al. [32] reported that the small nuclear EBV-encoded RNA-1 (EBER-1) signal was identified in the in- 
Table 5. Clinical characteristics of PCR-positive and/or ISH-positive cases, excluding EBV-positive gastric carcinoma cases

\begin{tabular}{|c|c|c|c|c|c|c|}
\hline & $\operatorname{PCR}(+)$ & $\operatorname{PCR}(-)$ & $\mathrm{ISH}(+)$ & $\mathrm{ISH}(-)$ & PCR $(+)$ and/or ISH $(+)$ & $\operatorname{PCR}(-)$ and $\operatorname{ISH}(-)$ \\
\hline No. of cases & 16 & 76 & 20 & 72 & 30 & 62 \\
\hline \multicolumn{7}{|l|}{ Sex } \\
\hline Male & 10 & 47 & 15 & 42 & 21 & 36 \\
\hline Female & 6 & 29 & 5 & 30 & 9 & 26 \\
\hline \multicolumn{7}{|l|}{ Site } \\
\hline Cardia & 3 & 21 & 8 & 16 & 10 & 14 \\
\hline Body & 8 & 34 & 6 & 36 & 11 & 31 \\
\hline Antrum & 5 & 21 & 6 & 20 & 9 & 17 \\
\hline \multicolumn{7}{|l|}{ Tumor depth } \\
\hline Early & 7 & 26 & 5 & 28 & 10 & 23 \\
\hline Advanced & 9 & 50 & 15 & 44 & 20 & 39 \\
\hline \multicolumn{7}{|l|}{ Histology } \\
\hline Intestinal & 5 & 32 & 6 & 31 & 10 & 27 \\
\hline Diffuse & 11 & 44 & 14 & 41 & 20 & 35 \\
\hline
\end{tabular}

Differences between EBV-positive cases and EBV-negative cases, excluding EBV-positive gastric carcinoma, were not significant

filtrating lymphocytes and shedding epithelial cells, predominantly in the fundic gland mucosa, of patients with EBV-positive gastric carcinoma. Yuen et al. [33] showed EBV-positive lymphoid cells in $50 \%$ of gastric carcinomas and in $33 \%$ of colorectal carcinomas. In 1997, Hoshida et al. [34] reported that positive signals were found in two of eight cases $(25.0 \%)$ in small lymphoid cells of gastric carcinoma in renal transplant recipients.

Yanai et al. [35] reported that EBV-determined nuclear antigen (EBNA)-1 immunostaining was observed in all 19 cases of atrophic gastric mucosa examined. But this finding is not likely to be confirmed, because of an inconsistency with ISH results and because they used a biotin method. In our series, EBV RNA was not detected in normal gastric epithelia.

In 2001, Cho et al. [36] reported that EBV-positive lymphocytes were seen in $10.7 \%$ of gastric carcinomas, $5.6 \%$ of esophageal carcinomas, $7.5 \%$ of ampulla of Vater cancers, and $12.8 \%$ of colorectal carcinomas. In our study, EBV genomes were detected in $21.6 \%$ of cases by a PCR method and in $24.7 \%$ of cases in infiltrating lymphocytes by the ISH method. Moreover, EBV-positive lymphocytes were observed in the cardia, body, and antrum (Table 5). These findings indicate the scattered presence of EBV in lymphocytes in the digestive tract, and emphasise the need to use morphological methods when assessing the EBV status of malignant digestive tract tumors.

The exact route through which EBV can enter epithelial cells is unknown, but, recently, some authors reported the establishment of EBV-positive gastric epithelial cell lines $[37,38]$. These cell lines may be useful for studying the interaction of EBV with gastric epithelial cells. In 1998, Imai et al. [39] demonstrated evidence for direct infection of various human epithelial cells by EBV in vitro. Cocultivation with virus produc- ers showed 800-fold-higher efficiency of infection than with cell-free infection, suggesting the significance of direct cell-to-cell contact as a mode of virus spread [39]. These cell lines and study systems will provide suitable materials for elucidating the interactions between EBV and epithelial cells.

In conclusion, EBV was detected in $5.2 \%$ of gastric carcinomas and in $24.7 \%$ of infiltrating lymphocytes by the ISH method. The high positive rate $(21.6 \%)$ by the PCR method corresponds to the presence of the EBV genome in surrounding lymphocytes.

Acknowledgments We wish to thank the members of the Department of Pathology, Chiba University, for their kindness and constant encouragement. This study was supported in part by a Grant-in-Aid for Scientific Research from the Japanese Ministry of Education, Culture, Sports, Science, and Technology (12671201).

\section{References}

1. Epstein A, Achong BG, Barr YM. Virus particles in cultured lymphoblasts from Burkitt's lymphoma. Lancet 1964;1:702-3.

2. zur Hauzen H, Schulte-Holthausen HS, Klein G, Henle W, Henle G, Clifford P, et al. EBV DNA in biopsies of Burkitt's tumors and anaplastic carcinomas of the nasopharynx. Nature 1970;228:10568.

3. Epstein A, Achong BG, editors. The Epstein-Barr virus. Tokyo New York Heidelberg Berlin: Springer-Verlag; 1979.

4. Lanier AP, Bornkamm GW, Henle W, Henle G, Bender TR, Talbot ML, et al. Association of Epstein-Barr virus with nasopharyngeal carcinoma in Alaskan native patients: serum antibodies and tissue EBNA and DNA. Int J Cancer 1981;28:301-5.

5. Weiss LM, Strickler JG, Warnke RA, Purtilo DT, Sklar J. Epstein-Barr viral DNA in tissues of Hodgkin's disease. Am J Pathol 1987;129:86-91.

6. Uhara H, Sato Y, Mukai K, Akao I, Matsuno Y, Furuya S, et al. Detection of Epstein-Barr virus DNA in Reed-Sternberg cells of Hodgkin's disease using polymerase chain reaction and in situ hybridization. Jpn J Cancer Res 1990;81:272-8. 
7. Herbst H, Niedobitec G, Kneba M, Hummel M, Finn T, Anagnostpoulos I. High incidence of Epstein-Barr virus genomes in Hodgkin's disease. Am J Pathol 1990;137:13-8.

8. Weiss LM, Chen YY, Liu XF, Shibata D. Epstein-Barr virus and Hodgkin's disease. Am J Pathol 1991;139:1259-65.

9. Jones JF, Shurin S, Abramowsky C, Tubbs RR, Sciotto CG, Wahl $\mathrm{R}$, et al. T-cell lymphomas containing Epstein-Barr viral DNA in patients with chronic Epstein-Barr virus infection. N Engl J Med 1988;318:733-41.

10. Hamilton-Dutoit SJ, Therkildsen MH, Nielsen NH, Jensen H, Hansen JPH, Pallsen G. Undifferentiated carcinoma of the salivary gland in Greenland Eskimos. Hum Pathol 1991;22:8115.

11. McGuire LJ, Huang DP, Teoh R, Arnord M, Fracs KW, Lee JCK. Epstein-Barr virus genome in thymoma and thymic hyperplasia. Am J Pathol 1988;131:385-90.

12. Weiss LW, Movahed LA, Bultler AE, Swanson SA, Frierson HF, Cooper PH, et al. Analysis of lymphoepithelioma and lymphoepithelioma-like carcinomas for Epstein-Barr viral genomes by in situ hybridization. Am J Surg Pathol 1989;13:625-31.

13. Saemundsen AK, Purtio DT, Sakamoto G, Sullivan JL, Synnerholm AC, Hanto D, et al. Documentation of Epstein-Barr virus infection in immunodeficient patients with life-threatening lymphoproliferative diseases by Epstein-Barr virus complementary RNA/DNA and viral DNA/DNA hybridization. Cancer Res 1981;41:4237-42.

14. Hamilton-Dutoit SJ, Pallesen G, Franzman MB, Karkov J, Black F, Skinhøj P, et al. AIDS-related lymphomas: histopathology, immunophenotype and association with Epstein-Barr virus as demonstrated by in-situ nucleic acid hybridization. Am J Pathol 1991;138:149-63.

15. Fukayama M, Ibuka T, Hayashi Y, Ooba T, Koike M, Mizutani S. Epstein-Barr virus in pyothorax-associated pleural lymphoma. Am J Pathol 1993;143:1044-9.

16. Sasajima Y, Yamabe H, Kobashi Y, Hirai K, Nori S. High expression of the Epstein-Barr virus latent protein EB nuclear antigen2 on pyothorax-associated lymphomas. Am J Pathol 1993;143 $1280-5$.

17. Burke AP, Yen TSB, Shekitka KM, Sobin LH. Lymphoepithelial carcinoma of the stomach with Epstein-Barr virus demonstrated by polymerase chain reaction. Mod Pathol 1990;3:377-80.

18. Shibata D, Tokunaga M, Uemura Y, Sato E, Tanaka S, Weiss LM. Association of Epstein-Barr virus with undifferentiated gastric carcinoma with intense lymphoid infiltration. Am J Pathol 1991; 139:469-74.

19. Shibata D, Weiss LM. Epstein-Barr virus-associated gastric carcinoma. Am J Pathol 1992;140:769-74.

20. Tokunaga M, Uemura Y, Tokudome T, Ishidate T, Masuda H, Okazaki E, et al. Epstein-Barr virus-related gastric cancer in Japan: a molecular patho-epidemiological study. Acta Pathol Jpn 1993;43:574-81.

21. Tokunaga M, Land CE, Uemura Y, Tokudome T, Tanaka S, Sato E. Epstein-Barr virus in gastric carcinoma. Am J Pathol 1993:143:1250-4.

22. Oda K, Tamaru J, Takenouchi T, Mikata A, Nunomura M, Saito $\mathrm{H}$, et al. Association of Epstein-Barr virus with gastric carcinoma with lymphoid stroma. Am J Pathol 1993;143:1063-71.
23. Nakamura S, Ueki T, Yao T, Ueyama T, Tsuneyoshi M. EpsteinBarr virus in gastric carcinoma with lymphoid stroma. Cancer 1994;73:2239-49.

24. Imai S, Koizumi S, Sugiura M, Tokunaga M, Uemura $Y$, Yamamoto N, et al. Gastric carcinoma: monoclonal epithelial malignant cells expressing Epstein-Barr virus latent infection protein. Proc Natl Acad Sci USA 1994;91:9131-5.

25. Mori M, Watanabe M, Tanaka S, Mimori K, Kuwano H, Sugimachi K. Epstein-Barr virus-associated carcinomas of the esophagus and stomach. Arch Pathol Lab Med 1994;118:9981001.

26. Harn HJ, Chang JY, Wang MW, Ho LI, Lee HS, Chiang JH, et al. Epstein-Barr virus-associated gastric adenocarcinoma in Taiwan. Hum Pathol 1995;26:267-71.

27. Moritani S, Kushima R, Sugihara H, Hattori T. Phenotypic characteristics of Epstein-Barr-virus-associated gastric carcinomas. J Cancer Res Clin Oncol 1996;122:750-6.

28. Galetsky SA, Tsvetnov VV, Land CE, Afanasieva TA, Petrovichev NN, Gurtsevitch VE, et al. Epstein-Barr-virusassociated gastric cancer in Russia. Int J Cancer 1997;73:786-9.

29. Lauren P. The two histological main types of gastric carcinoma: diffuse and so-called intestinal-type carcinoma: an attempt at a histoclinical classification. Acta Pathol Microbiol Scand 1965;64: 31-49.

30. Goelz SE, Hamilton SR, Vogelstein B. Purification of DNA from formaldehyde fixed and paraffin embedded human tissue. Biochem Biophys Res Commun 1985;130:118-26.

31. Furuta Y, Shinohara T, Sano K, Meguro M, Nagashima K. In situ hybridization with digoxigenin-labelled DNA probes for detection of viral genomes. J Clin Pathol 1990;43:806-9.

32. Fukayama M, Hayashi Y, Iwasaki Y, Chong J, Ooba T, Takizawa $\mathrm{T}$, et al. Epstein-Barr virus-associated gastric carcinoma and Epstein-Barr virus infection of the stomach. Lab Invest 1994;71: 73-81.

33. Yuen ST, Chung LP, Leung SY, Luk ISC, Chan SY, Ho J. In situ detection of Epstein-Barr virus in gastric and colorectal adenocarcinomas. Am J Surg Pathol 1994;18:1158-63.

34. Hoshida Y, Tomita Y, Ohsawa M, Ning Xu, Aozasa K. EpsteinBarr virus in malignancies in renal transplant recipients in Japan. J Cancer Res Clin Oncl 1997;123:509-13.

35. Yanai H, Takada K, Shimizu N, Mizugaki Y, Tada M, Okita K. Epstein-Barr virus infection in non-carcinomatous gastric epithelium. J Pathol 1997:183:293-8.

36. Cho YJ, Chang MS, Park SH, Kim HS, Kim WH. In situ hybridization of Epstein-Barr virus in tumor cells and tumor-infiltrating lymphocytes of the gastrointestinal tract. Hum Pathol 2001;32: 297-301.

37. Tajima M, Komuro M, Okinaga K. Establishment of Epstein-Barr virus-positive human gastric epithelial cell lines. Jpn J Cancer Res 1998;89:262-8

38. Iwasaki Y, JM Chong, Hayashi Y, Ikeno R, Arai K, Kitamura M, et al. Establishment and characterization of a human EpsteinBarr virus-associated gastric carcinoma in SCID mice. J Virol 1998;72:8321-6.

39. Imai S, Nishikawa J, Takada K. Cell-to-cell contact as an efficient mode of Epstein-Barr virus infection of diverse human epithelial cells. J Virol 1998;72:4371-8. 